\title{
Advisors' Understanding of Tax Compliance for Choice of Business Form
}

\author{
Brett Freudenberg*
}

\begin{abstract}
Choosing an appropriate business form is important for those commencing business, as making the wrong choice may result in economic inefficiencies for both the business and the broader economy. Given the life-cycle of businesses and regressive nature of compliance costs for small enterprises, to what extent are tax compliance cost considered by advisors and are they aware of the relevant empirical evidence? This paper details a study in 2007 that explored 81 advisors' understanding of the tax compliance cost issues that can arise in terms of business forms. The findings suggest that advisors have limited knowledge of the empirical evidence about tax compliance cost which may adversely impact their advice on business formation leading to long-term adverse economic implications.
\end{abstract}

JEL Codes: H22, H23 and K34

\section{Introduction}

While there are myriad business forms available, the corporation, in particular, has been perceived as contributing significantly to the economic development of countries (Harris 1994). This success has been attributed to the corporation's central characteristics of limited liability, continuity and transferable membership interests (Elias 1987). Countries such as Australia see the use of the corporation as inevitability linked to their future economic prosperity, with governments encouraging incorporation through lowering of the establishment fees and simplification of the regime.

However, it would be naive to think that the only business form is the corporation. The major business forms available in Australia extend from sole traders, through general partnerships, limited partnerships, discretionary trusts and unit trusts, to corporations. The most frequently used form is that of sole trader, although technically it is not a separate legal form.

The appropriate choice of business form is important for business operations, as it could impact both on the operations and the economy overall. For example, a business form could provide simple and clear default rules that could lead to networking benefits (Easterbrook \& Fischel 1991).

When considering income tax returns data, of the 2,906,073 taxpayers in 2010 who indicated that they were conducting a business, 36 per cent were sole proprietors, 27 per cent corporations, 24 per cent trusts and 13 per cent partnerships: Table 1 in Appendix.

\footnotetext{
${ }^{*}$ Associate Professor Brett Freudenberg, Griffith Business School, Griffith University, Brisbane, Queensland, phone: +61 73382 1196; email: b.freudenberg@griffith.edu.au.
} 


\section{Freudenberg}

In terms of size, 99.9 per cent of sole proprietors have less than $\$ 2$ million in turnover. Excluding those taxpayers who have 'nil business income', of the businesses with less than $\$ 10$ million income (categorised by the Australian Taxation Office (ATO) as 'small'), 45 per cent are sole proprietors, 28 per cent corporations, 14 per cent partnerships and 13 per cent trusts: Table 2 in Appendix. This means that business forms such as trusts and corporations are regularly used for small business operations.

Given the life-cycle model of businesses and the potential that many businesses may start up small before expanding, what consideration is given by advisors of tax compliance cost given its regressive nature? This is especially the case for small businesses, as many of them do not follow the complete life-cycle model, particularly never really expanding (Australian Chamber of Commerce and Industry 2003). Complexity is of concern for small businesses: research has demonstrated that they have the least capacity to cope with the burden of regulations (Small Business Deregulation Task Force 1996).

This article details a study of the considerations of advisors when they recommend a business form, particularly their understanding of the impact of tax compliance costs. This is important because if advisors have a limited understanding of compliance costs, then they may be recommending business forms that unduly add to the regulatory burden for businesses. While prior studies have considered what areas of tax law are considered complex by advisors (Tran-Nam \& Karlinsky 2008), this study explores whether advisors are aware of empirical studies and their consideration of this on business formation. Analysis of the findings raises concerns as there is limited knowledge of empirical evidence in this area.

The second section of this article outlines empirical evidence indicating that choice of business form may influence tax compliance costs and that this can be regressive for small businesses. Section Three outlines the methodology adopted in this study and Section Four gives the results. The final section suggests future research before concluding.

\section{Studies into Tax Compliance Cost}

This section discusses prior studies into tax compliance cost and how they indicate a relationship with choice of business form.

An important implication of choice of business structure is the regulatory and tax compliance burden that this may have. The Board of Taxation has identified that the choice of a complex business form can be a factor that drives up tax compliance costs (Board of Taxation 2007).

Literature describes how businesses can go through a life-cycle - a predictable progression of events. The Scott/Bruce cycle model has five stages: inception, survival, growth, expansion and maturity (Scott \& Bruce 1987). While such life-cycle models are not without their critics (McMahon 1998) it is argued that it useful to consider the life-cycle of businesses, especially as firms may start off small at inception. 


\section{Freudenberg}

A problem that has been highlighted by research is that when business operations are small their tax compliance cost can be regressive (Evans et al. 1997; Coleman \& Evans 2003; Ritchie 2002). Even if not regressive, compliance costs can detract from the economic efficiency of a business form, especially if there are insufficient benefits obtained from the compliance activity (Chittenden, Kauser \& Poutziouris 2000). Also compliance costs are not just purely financial, as non-financial costs can include stress and lost time (Board of Taxation 2007).

It is not clear whether the governance regime for the business form itself is the cause of this additional compliance cost or whether more sophisticated operations are attracted to certain business forms. Also, governments may introduce tax integrity measures targeting certain business forms if there is concern about aggressive tax planning.

The term tax compliance cost refers to 'the costs that taxpayers face as a result of complying with their taxation obligations' (Evans et al. 1997). Compliance cost can be distinguished between 'gross' and 'net', with net compliance cost reducing the gross figure by such advantages as tax deductibility of benefits, cash flow and managerial benefits (Lignier \& Evans 2012).

Of course tax is not the only compliance cost for businesses: the Working Overtime Survey found that on average small businesses spend 16 hours a week on administrative activities (Small Business Deregulation Taskforce 1996). Of this total, 12 hours are taken up with accounts, bookkeeping and paying wages, 4 hours are spent doing paperwork; and 3 hours go on taxation matters. That survey concluded that total compliance costs for small business were estimated to average AUD $\$ 7000$ a year. Of this, AUD $\$ 3000$ was spent on external advice. In terms of managing tax compliance costs, businesses can outsource their tax compliance by engaging a tax agent and/or bookkeeper to assist them, with 95 per cent of Australian small businesses having a tax agent to prepare their income tax returns (Board of Taxation 2007).

The Australian tax compliance cost study by Evans et al. found that small business personnel devoted an average of 3.6 hours per month to tax compliance matters, with 2.4 hours of that total being devoted to income tax compliance (Evans et al. 1996). It has been estimated that taxation accounts for roughly two thirds (or 141 hours per annum) of all time spent on compliance activities by small businesses in Australia (Small Business Deregulation Taskforce 1996).

The regressive nature of compliance cost was demonstrated by Evans et al.: the average compliance cost per $\$ 1000$ of turnover for small businesses was $\$ 34.13$, whereas for a large business it was $\$ 1.84$. While this improved once tax deductibility of costs was factored, there still remained a large differential: Table 3.

The Evans et al. study demonstrates how choice of structure may impact on tax compliance cost, as an Australian small business operating through a trust structure had on average 178 per cent greater compliance cost than one operating through a corporation, and 206 per cent greater cost than for a general partnership. Once the tax deduction for compliance cost is taken into account, businesses operating as a trust have on average 194 per cent greater compliance cost than corporations. This 


\section{Freudenberg}

finding was duly noted in the report but no real analysis occurred as to why this might be the case.

Table 3: AUS: Average compliance cost

\begin{tabular}{|l|l|l|l|}
\hline Type of Business & $\begin{array}{l}\text { Small } \\
(<\mathbf{A} \mathbf{1 0 0 , 0 0 0})\end{array}$ & $\begin{array}{l}\text { Medium } \mathbf{( 1 0 0 , 0 0 0} \\
\text { to A\$9,999,999) }\end{array}$ & $\begin{array}{l}\text { Large } \mathbf{A} \mathbf{A} \mathbf{\$ 1 0} \\
\text { million) }\end{array}$ \\
\hline Sole Trader & 27.72 & 1.28 & N/A \\
\hline Partnerships & 31.74 & 1.54 & 0.72 \\
\hline Trusts & 65.44 & 1.55 & 0.32 \\
\hline Superannuation Funds & 32.08 & 1.78 & 1.49 \\
\hline Companies & 36.68 & 1.98 & 1.93 \\
\hline Overall Compliance Costs & 34.13 & 1.74 & 1.84 \\
\hline $\begin{array}{l}\text { Overall Compliance Costs After Tax } \\
\text { Deductions }\end{array}$ & 26.96 & 1.18 & 1.34 \\
\hline Overall Average Compliance Costs & 24.71 & 0.98 & 0.60 \\
Source: Evans et al. 1996. & \multicolumn{2}{l}{} \\
\hline
\end{tabular}

It should be noted that for medium and large businesses, the corporation had the greater compliance cost, which may, in part, be attributed to the popularity of this form for larger scale activities.

More recently, Lignier and Evans confirmed that tax compliance costs continue to be regressive, particularly at the lower end of small business (less than \$3M) (Lignier \& Evans 2012). Unfortunately, to date there has been no reporting as to whether the choice of business form related to the compliance cost experienced by the businesses. It is understood that this is due to the small sample size and the skewing of respondents using the corporate form.

Other jurisdictions also demonstrate how the type of business form may impact on tax compliance cost. For example, in New Zealand the study by Colmar Brunton tends to indicate that partnerships have lower compliance costs than corporations but not lower than individuals (Colmar Brunton 2005). This is further supported by a small study by Ritchie where the general partnership form had the lowest tax compliance hours compared to others utilising the corporate or the tax flow-through company of the Loss Attributing Qualifying Company (LAQC) (Ritchie 2001; Ritchie 2002).

Furthermore, there is evidence from the United States with the study by DeLuca et al. (2005) demonstrating that general partnerships had the lowest overall tax compliance costs of all business forms, followed by the $\mathrm{C}$ Corporation, then the tax flow-through companies of $\mathrm{S}$ Corporations and the Limited Liability Companies (LLCs).

Overall, these studies suggest that the choice of business form can have legacy issues in terms of tax compliance costs. The reasons for this could include the business form itself or its use in more complex areas or in aggressive tax planning strategies. Such legacy issues could be important as many small businesses do not expand and, therefore, the regressive nature of tax compliance cost and its relationship to business form is important.

To date there has not been an Australian study considering whether advisors are aware of this empirical research about how business-form choice could impact on tax compliance cost. This is of concern as advisors may be recommending forms that unduly add compliance burden for clients. 


\section{Freudenberg}

\section{Research Study}

The research detailed in this article had the aim better to understand to what extent do Australian advisors consider tax compliance costs in the choice of business form which is an area that prior studies have not explored. To address this research aim this study explores: (i) to what extent advisors are aware of empirical evidence (and if so, the source); (ii) how advisors ranked business forms in terms of tax compliance cost (and the impact of business size had with this); and (iii) whether advisors' opinions in relation to (ii) were consistent with empirical evidence and whether this varied as to their awareness of this evidence.

To address this research aim, a quantitative survey was implemented. The wording of the survey instrument was developed from prior literature with the endeavour to address the research aims. The draft instrument was then pilot- tested with five advisors to gauge its readability and to clarify any questions. This process resulted in a few changes and clarifications to the survey instrument. The final survey instrument consisted of three parts, the first two being relevant for this article. The first part requested brief demographic details. Within the second part questions were posed to gauge awareness of tax compliance costs studies and the impact that choice of business form could have.

To facilitate data collection, a survey was conducted in 2007 of 81 advisors in Queensland attending six continuing professional development (CPD) seminars conducted by the Tax Institute. Approximately 240 advisors were in attendance at these seminars. This is a similar number of participants in prior research into advisors' opinions about taxation complexity in Australia (Tran-Nam \& Karlinsky 2008: with 121 advisors) and was considered sufficient given the exploratory nature of this research. Also given the national application of business forms and income tax, the sampling of Queensland advisors may not constitute a significant bias. The Taxation Institute is a professional body representing tax practitioners; the CPD seminars were an assembly of its members and prospective members. This formed the exact pool of potential respondents required to perform the survey. Due to the sample size and the jurisdictional restraints, the findings of this study may not be representative; however, they may demonstrate interesting trends.

Table 4 presents summary demographic statistics of the survey participants. Broadly, there was a balance in terms of gender, age, position and number of years of experience. With regard to the highest completed level of education, the cluster in the CPA/CA bracket was expected as the majority of degree-qualified accountants continue their professional development, gaining either CPA or CA status for career advancement purposes. 
Freudenberg

Table 4: Demographics of participants

\begin{tabular}{|lll|}
\hline Variable & Factors & Values \\
\hline $\mathrm{N}$ & & 81 \\
\hline Gender & Male & $55 \%$ \\
& Female & $45 \%$ \\
\hline Age & 25 or Less & $19.8 \%$ \\
& $26-35$ & $37.0 \%$ \\
& $36-45$ & $22.2 \%$ \\
& Greater than 45 & $19.8 \%$ \\
& Not Stated & $1.2 \%$ \\
\hline Position & Junior Accountant & $13.6 \%$ \\
& Senior Accountant & $16.0 \%$ \\
& Manager & $21.0 \%$ \\
& Partner/Director & $30.9 \%$ \\
& In-house Account & $3.7 \%$ \\
& Lawyer & $7 \%$ \\
& Other & $7.8 \%$ \\
\hline Number of Years Experience & $0-1$ years & $6.2 \%$ \\
& $1-3$ years & $13.6 \%$ \\
& $3-6$ years & $18.5 \%$ \\
& $6-10$ years & $16.0 \%$ \\
& $10-15$ years & $13.6 \%$ \\
& $>15$ years & $32.1 \%$ \\
\hline Highest Completed Education & Below Grade 12 & $0.0 \%$ \\
& Grade 12 & $0.0 \%$ \\
& Bachelor & $19.8 \%$ \\
& Honours/Masters & $17.3 \%$ \\
& CPA/CA & $63.0 \%$ \\
\hline
\end{tabular}

Accountants made up a large percentage of participants ( 85 per cent) with only a few lawyers (seven per cent). However, given the substantial role that accountants can play in the choice of business form, it may be that the opinions of accountants are insightful to the considerations at play (Hicks, Drury \& Smallcombe 1995).

\section{Findings}

When respondents were asked whether they were aware of empirical research on how the choice of business form affects tax compliance cost, only 24.7 per cent noted any awareness. This means that a vast majority ( 75.3 per cent) are using only their own professional judgment when considering the impact of tax compliance cost for their clients. The 20 respondents aware of empirical evidence indicated that this evidence was mainly from professional journals ( 80 per cent), newspaper and media release (20 per cent each): Figure 1. Academic journals and university research were indicated as the source by only 15 per cent and 10 per cent, respectively (note that respondents could nominate a number of sources for their information). Such a finding is of concern about the impact that academic research has if it is not disseminated through professional journals and the media, as traditional academic modes of dissemination appear to have minimal impact on the profession. 


\section{Freudenberg}

Figure 1: Source of awareness of empirical research

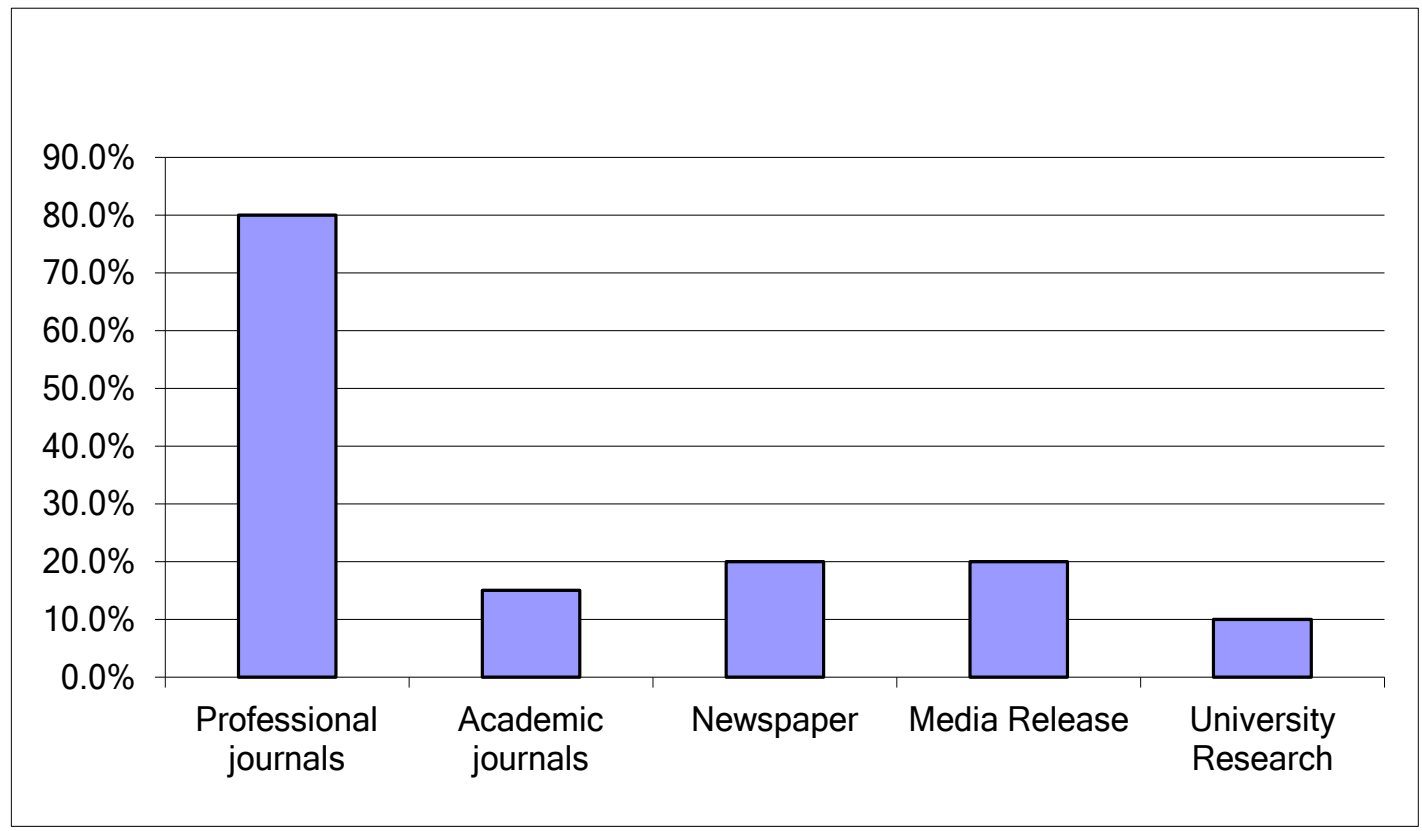

When asked to rank five business forms in terms of related tax compliance costs (1 lowest, 5 highest), respondents on average identified sole traders (1.42 average) and general partnerships (2.18) as providing the lowest tax compliance costs: Figure 2Figure 2. In terms of trusts, respondents considered that discretionary trusts (3.59) and unit trusts (3.73) had similar average tax compliance costs and were in the middle of the business forms range provided. Companies were identified as having the highest (on average) tax compliance cost (4.08). These results were similar for senior advisors (those with greater than ten years experience) and junior advisors.

This question had no 'size' indicator of the business form, and so it may be that companies were identified as having the highest tax compliance costs: they can dominate as the business form of choice when the operations are large. Also, the study by Evans et al. (1996) found that corporations did have the highest tax compliance cost when turnover exceeded $\$ 100,000$.

Figure 2: Ranking of business forms: tax compliance cost

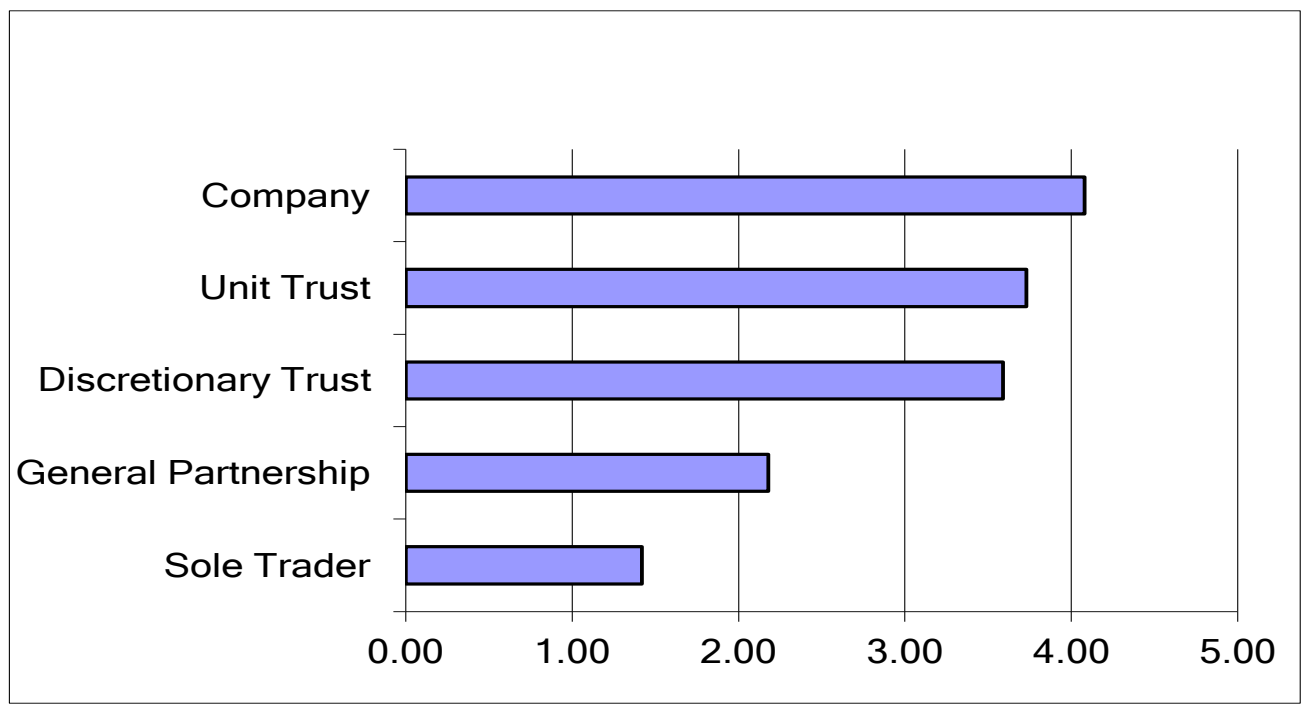

(Average ranking of five business forms ( $1=$ lowest; 5 highest) in terms of related tax compliance cost.) 


\section{Freudenberg}

To delineate whether turnover would affect perception of tax compliance costs, participants were asked to rank the five business forms in four scenarios: when annual turnover was \#1: $<\$ 50,000$; \#2: $\$ 50,000$ to $\$ 200,000 ; \# 3$ : $\$ 200,000-\$ 1 \mathrm{M}$ and \#4: $\$ 1 \mathrm{M}$ to $\$ 20 \mathrm{M}$. Inconsistent with the research by Evans et al. for the small business scenarios (\#1 and \#2), here trusts were not identified as having greater tax compliance than companies: Table 5. It appears that the consideration of turnover did not greatly affect the ranking of tax compliance cost for the business forms considered, as the ranking of business forms was similar to when no turnover was provided. Except for scenario \#4 when unit trusts were slightly (0.04) more complex than companies, with the different turnovers provided, the business forms were consistently ranked in terms of tax compliance cost as follows (in ascending order): sole traders, general partnerships, discretionary trusts, unit trusts and companies. Similar results were obtained when comparing senior advisors' and junior advisors' responses. It would appear that advisors have an established perception of compliance cost relevant to the business form and that this is not largely impacted by turnover.

Table 5: Ranking of business forms' tax compliance cost given turnover

\begin{tabular}{|l|l|l|l|l|}
\hline Business form & $\begin{array}{l}\text { Scenario \#1 } \\
\text { turnover }< \\
\mathbf{\$ 5 0 , 0 0 0}\end{array}$ & $\begin{array}{l}\text { Scenario \#2 } \\
\text { turnover } \\
\mathbf{\$ 5 0 , 0 0 0}- \\
\mathbf{\$ 2 0 0 , 0 0 0}\end{array}$ & $\begin{array}{l}\text { Scenario \#3 } \\
\text { turnover } \\
\mathbf{\$ 2 0 0 , 0 0 0} \text { to } \\
\mathbf{\$ 1} \mathbf{M}\end{array}$ & $\begin{array}{l}\text { Scenario \#4 } \\
\text { turnover } \mathbf{\$ 1} \\
\text { to } \mathbf{\mathbf { 2 0 M }}\end{array}$ \\
\hline Sole trader & 1.34 & 1.42 & 1.43 & 1.52 \\
\hline General partnership & 2.27 & 2.26 & 2.17 & 2.43 \\
\hline Discretionary trust & 3.45 & 3.33 & 3.38 & 3.29 \\
\hline Unit trust & 3.86 & 3.88 & 4.00 & $3.9^{*}$ \\
\hline Company & $4.07^{*}$ & $4.12^{*}$ & $4.02^{*}$ & 3.86 \\
\hline
\end{tabular}

(Average ranking score where $1=$ the lowest and $5=$ the highest. '*' indicates the form with the average highest rating for each scenario).

However, those respondents aware of empirical research on tax compliance cost showed some difference: they noted that both types of trusts (discretionary and unit trust) would have the greatest tax compliance burden when turnover was less than $\$ 50,000$ : Table 6. After that threshold there was an opinion that unit trusts would provide the greatest compliance cost burden - even greater than corporations. This could relate to the fact that, for larger business operations, unit trusts may be used more than discretionary trusts due to their ability to raise equity through issuing units. For those participants unaware of empirical research, the company was considered the business form with the highest tax compliance cost, regardless of turnover. These findings would tend to indicate that for many advisors the size of business operations does not affect tax compliance costs. For those with some awareness of empirical evidence, there was some appreciation that the trusts used for business operations could lead to greater tax compliance costs. 


\section{Freudenberg}

Table 6: Ranking of business forms' tax compliance cost given turnover (aware and unaware of research)

\begin{tabular}{|l|l|l|l|l|l|l|l|l|}
\hline $\begin{array}{l}\text { Business } \\
\text { form }\end{array}$ & $\begin{array}{l}\text { Scenario \#1 } \\
\text { turnover < } \\
\mathbf{\$ 5 0 , 0 0 0}\end{array}$ & $\begin{array}{l}\text { Scenario \#2 } \\
\text { turnover } \\
\mathbf{\$ 5 0 , 0 0 0}- \\
\mathbf{\$ 2 0 0 , 0 0 0}\end{array}$ & \multicolumn{2}{l|}{$\begin{array}{l}\text { Scenario \#3 } \\
\text { turnover } \mathbf{\$ 2 0 0 , 0 0 0} \\
\text { to \$1M }\end{array}$} & \multicolumn{2}{l|}{$\begin{array}{l}\text { Scenario \#4 } \\
\text { turnover \$1M to } \\
\mathbf{\$ 2 0 M}\end{array}$} \\
\cline { 2 - 9 } & Aware & Unaware & Unaware & Aware & Unaware & Aware & Unaware \\
\hline Sole trader & 2.33 & 1.18 & 2.33 & 1.27 & 2.33 & 1.28 & 2.33 & 1.39 \\
\hline $\begin{array}{l}\text { General } \\
\text { partnership }\end{array}$ & 2.50 & 2.24 & 2.50 & 2.22 & 2.33 & 2.14 & 2.33 & 2.44 \\
\hline $\begin{array}{l}\text { Discretion'a } \\
\text { ry trust }\end{array}$ & 3.33 & 3.47 & 2.67 & 3.43 & 2.50 & 3.53 & 2.67 & 3.39 \\
\hline Unit trust & $3.83^{*}$ & 3.87 & $3.83^{*}$ & 3.89 & $4.33^{*}$ & 3.94 & $4.33^{*}$ & 3.83 \\
\hline Company & 3.00 & $4.24^{*}$ & 3.67 & $4.19^{*}$ & 3.50 & $4.11^{*}$ & 3.33 & $3.94^{*}$ \\
\hline
\end{tabular}

(Average ranking score where $1=$ the lowest and $5=$ the highest. 'Aware indicates aware of empirical research, 'Unaware' indicates unaware of empirical research. ' ${ }^{*}$ ' indicates the form with the average highest rating for each scenario)

The findings of this study build upon the prior literature that demonstrates that the choice of business form can influence tax compliance cost. These findings may be of concern as it may be that advisors do not fully appreciate or take into account how their advice on choice of business form may be impacting on their clients' tax compliance costs, as a large percentage was unaware of the empirical evidence. The potential adverse nature of this lack of knowledge appears to influence advisors' understanding of tax compliance cost, as those unaware generally chose the corporation as the form related to greater compliance cost. Whereas those aware of empirical evidence consider that unit trusts were associated with greater cost. This is supported by the finding of a subsequent question where 68 per cent of respondents acknowledged that their clients' business form could be too complicated for their needs (either sometimes or frequently).

\section{Limitations \& Conclusion}

This section highlights the limitations of this research, as well as noting the potential for future research.

\subsection{Limitations and Future Research}

It is acknowledged that this research has only a small sample size and may have jurisdictional bias as only Queensland advisors were surveyed. Also, there was a high proportion of accountants in the survey and their opinions may not be reflective of other professionals involved in giving advice about business formation. However, it is contended that the study provides a foundation on which future research can be tested and built upon.

Future research could consider how academic research could have a larger impact on the profession, in terms of providing empirical evidence to inform advisors' decisions. Research could consider which characteristics of business forms (or the legislation that applies to them) contribute to their tax compliance costs. 


\section{Freudenberg}

\subsection{Conclusion}

While prior studies have demonstrated that the choice of business form can influence tax compliance cost, this study uniquely considers whether advisors are aware of this evidence. This is important as advisors may be recommending business forms to their clients that may be unnecessarily increasing the tax compliance costs; a factor acknowledge by over two-thirds of participants.

The choice of business form is important because if the wrong choice is made it could have legacy issues which could lead to adverse economical consequences. This study demonstrates that while knowledge of empirical studies on tax compliance cost was low, those who were aware of empirical studies showed a tendency to see trusts (especially unit trusts) as imposing greater tax compliance costs. For those unaware of empirical studies on tax compliance cost, there was a consistent ranking of tax compliance cost in the following ascending order: sole traders, general partnerships, discretionary trusts, unit trusts and companies. It is argued that this is of concern as such a ranking is inconsistent with empirical evidence which demonstrates that trusts can have a higher tax compliance cost when operations are small.

It is important that future research explores the important decision-making process that occurs on the formation of a business, to ensure that appropriate decisions are being made.

\section{Acknowledgement}

I would like to thank Danny Riggs for his research assistance in the collation of the data. 


\section{Freudenberg}

\section{References}

Australian Chamber of Commerce and Industry 2003, Evaluation of Small Business Assistance Programs: ACCl Submissions to the Office of Small Business, Barton.

Australian Taxation Office 2012 Taxation Statistics: A summary of tax returns for the 2006 to 2010 income years, Australian Taxation Office, Canberra.

Board of Taxation 2007, Scoping study of small business tax compliance costs: A report to the Treasurer, Attorney-General's Department, Canberra.

Chittenden, F, Kauser, S \& Poutziouris, P 2000, Regulatory Burdens of Small Business: A Literature Review, University of Manchester.

Coleman, C, \& Evans, C 2003, 'Tax Compliance Issues for Small Business in Australia' in N Warren (ed.), Taxing Small Business: Developing Good Tax Policies, Australian Tax Research Foundation: Sydney, pp.147-181.

Colmar Brunton 2005, Measuring the tax compliance costs of small and mediumsized business - a benchmark survey: Final Report, New Zealand.

DeLuca, D, Greenland, A, Guyton, J, Hennessy, S, \& Kindlon, A 2005, 'Measuring the Tax Compliance Burden of Small Business', Proceedings of Internal Revenue Services' Research Conference, 7-8 June, Washington DC.

Easterbrook, FH, \& Fischel, DR 1991, The Economic Structure of Corporate Law, Harvard University Press, Cambridge.

Elias, S, 1987 Contemporary Issues in Company Law, CCH, New Zealand.

Evans C, Ritchie, K, Tran-Nam, B \& Walpole, M 1996, A Report into the Incremental Costs of Taxpayer Compliance, AGPS, Canberra.

Harris, PA 1996, Corporate/Shareholder Income Taxation and Allocating Taxing Rights Between Countries: A Comparison of Imputation Systems, IBFD Publications BV, Amsterdam.

Hicks, A, Drury, R \& Smallcombe, J 1995, Alternative Company Structures for the Small Business, ACCA Research Report No 42, Certified Accountants Educational Trust, London.

Lignier, P \& Evans, C 2012 'The rise and rise of tax compliance costs for the small business sector in Australia', Australian Tax Forum, Vol. 27, no. 3, pp 615-672.

McMahon, RGP 1998, 'Stage Models of SME Growth Reconsidered', School of Commerce Research Papers Series.

Ritchie, K 2001, 'A Year in the Life of the Tax Compliance Costs of Some Small New Zealand Businesses', Paper presented to the 13th Annual Australasian Tax Teachers Association Conference, February 2001, at Sydney.

Ritchie, K 2002, New Zealand Small Business Tax Compliance Costs - Some Empirical Evidence, Inland Revenue, Wellington.

Scott, M \& Bruce, R 1987, 'Five Stages of Growth in Small Business', Long Range Planning, vol. 20. no. 3, pp. 45-52.

Small Business Deregulation Task Force 1996, Time for Business, AGPS, Canberra.

Tran-Nam B \& Karlinsky, S 2008, 'Small Business Tax Law Complexity in Australia', in M Walpole and C Evans (eds.), Tax Administration: Safe Harbours and New Horizons, Fiscal Publications, Birmingham, pp. 321-348. 


\section{Freudenberg}

\section{Appendix}

Table 1: AUS: Lodgement of Tax Returns - Business

\begin{tabular}{|l|l|l|l|l|}
\hline Business form & $2006-07$ & $2007-08$ & $2008-09$ & $2009-10$ \\
\hline Sole proprietor & 958,489 & $1,058,302$ & $1,005,567$ & $1,044,386$ \\
\hline Partnerships & 419,246 & 419,315 & 393,115 & 382,400 \\
\hline Trusts & 609,915 & 660,324 & 659,744 & 702,080 \\
\hline Corporations & 750,227 & 772,435 & 762,442 & $777,207^{*}$ \\
\hline Total & $2,737,877$ & $2,910,376$ & $2,820,868$ & $2,906,073$ \\
\hline
\end{tabular}

Source: (Australian Taxation Office 2012).

Table 2: AUS: Lodgement of Tax Returns - Size

\begin{tabular}{|l|l|l|l|l|l|l|l|}
\hline Business form & $\begin{array}{l}\text { Loss } \\
<\$ 0\end{array}$ & $\begin{array}{l}\text { Nil } \\
=\$ 0 \text { (ie not } \\
\text { in business) }\end{array}$ & $\begin{array}{l}\text { Micro } \\
>\$ 0 \text { but }< \\
\$ 2 \mathrm{M}\end{array}$ & $\begin{array}{l}\text { Small } \\
>\$ 2 \mathrm{M} \\
\text { but } \\
<\$ 10 \mathrm{M}\end{array}$ & $\begin{array}{l}\text { Medium } \\
>\$ 10 \mathrm{M} \\
\text { but }< \\
\$ 100 \mathrm{M}\end{array}$ & $\begin{array}{l}\text { Large } \\
>\$ 100 \mathrm{M} \\
\text { but }< \\
\$ 250 \mathrm{M}\end{array}$ & $\begin{array}{l}\text { Very } \\
\text { Large } \\
> \\
\$ 250 \mathrm{M}\end{array}$ \\
\hline $\begin{array}{l}\text { Sole } \\
\text { proprietor }\end{array}$ & 1,352 & $11,335,642$ & $1,038,850$ & 3,734 & 445 & 2 & 3 \\
\hline Partnerships & 301 & 69,481 & 304,414 & 7,139 & 979 & 54 & 30 \\
\hline Trusts & 727 & 405,871 & 271,285 & 20,281 & 3,754 & 122 & 38 \\
\hline Corporations & 1,817 & 110,598 & 600,431 & 49,419 & 12,916 & 1,099 & 927 \\
\hline
\end{tabular}

Source: (Australian Taxation Office 2012). 